\title{
Sentralnervesystemets dynamikk i bilder
}

Nå tegnes det et rikt bilde av intra- og interindividuelle forskjeller i hjernen gjennom livet. Kvantitative analyser av MR-bilder gir oss detaljert informasjon om hjernen i endring. Eksempelvis har forskning på effekten av kognitiv trening avdekket plastiske endringer i hjernebarkens tykkelse på submillimeternivå etter at treningen har pågått noen uker (1). Ulike MR-teknikker utfyller bildet, med ny kunnskap om mikrostrukturelle trekk og mønstre av hjerneaktivitet (2). MR-undersøkelse gir et unikt innblikk i dynamikken i sentralnervesystemet.

I dette nummer av Tidsskriftet stiller Unn Kristin Haukvik og medarbeidere spørsmålet om man kan se schizofreni på MR-bilder (3). Artikkelen gir en utmerket og svært interessant innføring i nevroanatomiske forhold ved sykdommen. Forfatterne diskuterer hvorvidt man ut fra MR-bilder kan si noe utover tilstedeværelse eller fravær av hjerneorganiske patologiske funn, om MR-undersøkelse kan gi økt kunnskap om de patofysiologiske prosessene - og om man ut fra undersøkelsen kan skille friske og syke. De svarer ja på de to første spørsmålene og nei på det siste.

Forskjeller finnes på gruppenivå, men vi kan ikke ut fra bildene sikkert skille friske og syke. Hvorfor er det slik? Svaret kan dels gis ut fra det bildet ny forskning nå danner av stor normalvariasjon og kontinuerlig endring og at kliniske tilstander ikke nødvendigvis skiller seg kategorisk fra normaltilstander - disse eksisterer langs et kontinuum.

Haukvik og medarbeidere peker på at noen hjernestrukturer gjennomsnittlig er mindre hos schizofrene (3), men at overlappingen mellom friske og syke er stor. Den brede normalvariasjonen gjør muligheten for å bruke MR-undersøkelse i diagnostikk av flere tilstander til en stor utfordring - den voksne hjernen veier typisk mellom $1,2 \mathrm{~kg}$ og 1,5 kg, og denne differansen på $300 \mathrm{~g}$ vil langt overstige den effekt på hjernen som sykdom kan ha. Livsløpsforskning viser at normalvariasjonen øker med stigende alder, noe som ytterligere kompliserer bildet.

I dag vet vi at hjernen er i kontinuerlig endring, med ulike utviklings-, aldrings- og sykdomsforløp for forskjellige strukturer. Hippocampus viser for eksempel et komplekst forløp - med langvarig volumøkning også hos unge voksne, for så å være preget av akselererende reduksjon i høy alder. Akselererende reduksjon kan være uttrykk for sykdom, men også for normal aldringsendring. Likevel kan MR-undersøkelse av mediale temporallapper bidra til diagnose av Alzheimers demens (4). Spørsmålet er hvor tidlig i sykdomsutviklingen undersøkelsen kan gi informasjon. Her flyttes grensene. Som Haukvik og medarbeidere påpeker kan sykdommer som schizofreni ha en etiologi relatert til utviklingen av sentralnervesystemet (3). Vi må vite mer også om normale utviklingsforløp for å kunne belyse dette. Nevroepidemiologiske MR-studier inkorporerer informasjon om tidlig utvikling, også pre-, peri- og neonatale forhold $(5,6)$. Vi vil forhåpentligvis kunne dra nytte av flere slike pågående og fremtidige studier som følger hjernefunksjon og kognitiv funksjon hos brede og godt karakteriserte grupper. Her i Norge har vi utmerkede muligheter til å bidra, ved at vi kan følge store grupper, gjerne knyttet opp mot helseregistre som Medisinsk fødselsregister.

Nyere forskning har nyansert bildet av utviklingsforstyrrelser med nevral etiologi. Eksempelvis er det blitt klart at de forskjellene man finner på gruppenivå mellom barn med atferdsforstyrrelser og asymptomatiske barn, eksisterer langs et kontinuum. Det har vist seg at barn som ikke møter diagnostiske kriterier, men har enkelte atferds-, hyperaktivitets- eller oppmerksomhetsvansker, også har noen av de samme trekkene ved hjernebarken, bare i mindre grad $(7,8)$. Det samme ser vi når det gjelder fødselsvekt - svært lav fødselsvekt kan gi økt risiko for enkelte utviklingsforstyrrelser, men fødselsvekten korrelerer med nevroanatomiske forhold også langs hele normalvariasjonen (9). Det blir altså ikke snakk om hvorvidt nevroanatomiske trekk er til stede eller ikke, men i hvilken grad. Schizofreni er en gjennomgripende forstyrrelse, men undersøkelser av personer med schizofrent spektrum-forstyrrelser tyder på at nevrokognitive trekk kan finnes på tvers av diagnoser (10), noe som støtter et dimensjonalt syn også her.

Det er klart, som forfatterne påpeker for schizofreni, at MR-undersøkelser i dag kan belyse de patofysiologiske prosessene som knyttes til en rekke kliniske tilstander. Slike undersøkelser gir likevel ikke innblikk i prosessene på molekylært nivå. Selv om nye teknikker kan bidra, er det behov for kombinerte dyre- og menneskemodeller der MR-funnene kan knyttes til histologiske og histokjemiske analyser. Utvidet tverrfaglig samarbeid og økt finansieringsvilje vil kunne føre langt også på dette feltet.

\section{Kristine B. Walhovd}

k.b.walhovd@psykologi.uio.no

Kristine B. Walhovd (f. 1976) er professor i nevropsykologi ved Psykologisk institutt, Universitetet i Oslo. Sammen med Anders M. Fjell leder hun Forskningsgruppe for livsløpsendringer i hjerne og kognisjon.

Forfatter har fylt ut ICMJE-skjemaet og oppgir følgende interessekonflikter: Hun har mottatt honorar/reisestøtte fra Institute for Life Sciences i Brussel.

\section{Litteratur}

. Engvig A, Fjell AM, Westlye LT et al. Effects of memory training on cortical thickness in the elderly. Neuroimage 2010; 52: 1667-76.

2. Fjell AM, Walhovd KB, Brown TT et al. Multimodal imaging of the self-regulating developing brain. Proc Natl Acad Sci U S A 2012; 109: 19620-5.

3. Haukvik UK, Hartberg CB, Agartz I. Schizofreni - hva viser strukturell MR? Tidsskr Nor Legeforen 2013; 133: 850-3.

4. McKhann GM, Knopman DS, Chertkow $\mathrm{H}$ et al. The diagnosis of dementia due to Alzheimer's disease: recommendations from the National Institute on AgingAlzheimer's Association workgroups on diagnostic guidelines for Alzheimer's disease. Alzheimers Dement 2011; 7: 263-9.

5. White T, Marroun HE, Nijs I et al. Pediatric population-based neuroimaging and the Generation R Study: the intersection of developmental neuroscience and epidemiology. Eur J Epidemiol 2013; 28: 99-111.

6. Paus T. Population neuroscience: why and how. Hum Brain Mapp 2010; 31 $891-903$.

7. Walhovd KB, Tamnes CK, Ostby Y et al. Normal variation in behavioral adjustment relates to regional differences in cortical thickness in children. Eur Child Adolesc Psychiatry 2012; 21: 133-40.

8. Shaw P, Gilliam M, Liverpool M et al. Cortical development in typically developing children with symptoms of hyperactivity and impulsivity: support for a dimensional view of attention deficit hyperactivity disorder. Am J Psychiatry 2011: 168: 143-51.

9. Walhovd KB, Fjell AM, Brown TT et al. Long-term influence of normal variation in neonatal characteristics on human brain development. Proc Natl Acad Sci U S A 2012; 109: 20089-94.

10. Simonsen C. Sundet K, Vaskinn A et al. Neurocognitive dysfunction in bipola and schizophrenia spectrum disorders depends on history of psychosis rather than diagnostic group. Schizophr Bull 2011; 37: 73-83. 